\title{
'Icicle': A White Lance-leaved Caladium Cultivar for Containers and Shady Landscapes
}

\author{
Zhanao Deng ${ }^{1}$ \\ Department of Environmental Horticulture, University of Florida, IFAS, \\ Gulf Coast Research and Education Center, 14625 County Road 672, \\ Wimauma, FL 33598
}

\section{Natalia A. Peres}

Department of Plant Pathology, University of Florida, IFAS, Gulf Coast Research and Education Center, 14625 County Road 672, Wimauma, FL 33598

Caladiums (Caladium $\times$ hortulanum Birdsey, Araceae Juss.) can be grown in containers or planted in the landscape as accent and border plants (Evans et al., 1992). They are valued for their long-lasting colorful foliage. Most of the commercially available caladium plants are forced from tubers. Florida growers supply essentially all the caladium tubers used in the United States and some 40 countries in the world for the production of pot plants and direct planting in the landscapes. New cultivar introductions are important not only to the Florida caladium industry but also to the greenhouse, nursery, and landscape industries.

Commercial caladium cultivars are often grouped into eight categories based on their leaf type and impact color [fancy white, red, pink, and novelty, and lance (or strap) white, red, pink, and novelty] (Bell et al., 1998). Recent surveys of the Florida caladium industry indicated that 51 caladium cultivars were planted in 2013 with two or more acres planted per cultivar (Deng et al., 2008; Z. Deng, unpublished data). Among the white lance-leaved cultivar groups are 'Florida White Ruffles' and 'White Wing'. 'Florida White Ruffles' was released by the University of Florida/Institute of Food and Agricultural Sciences caladium breeding program in 2001. It was primarily bred for forcing in small containers and hanging baskets

Received for publication 16 Mar. 2018. Accepted for publication 25 Apr. 2018.

The development and evaluation of 'Icicle' caladium were funded in part by the USDA hatch projects (Project \# FLA-GCR-005065 and FLAGCC-005507), Florida caladium growers' "box assessment," and royalties from previously released caladium cultivars.

We thank Joyce Jones, Gail Bowman, and Teresa Seijo for their excellent technical support, and Bates Sons \& Daughters, Inc., Happiness Farms, Inc., and Hendry Caladiums, Inc. for evaluating 'Icicle'. The Osmocote ${ }^{\circledR}$ fertilizer used in field and greenhouse trials was donated by the Scotts Miracle-Gro Company and the potting mix Fafard 3B was donated by Fafard, Inc. (Apopka, FL). ${ }^{1}$ Corresponding author. E-mail: zdeng@ufl.edu.
(Baldwin et al., 2002). 'White Wing' has been in commercial production for many years and was ranked 3rd among all lanceleaved cultivars in the acreage planted in 2013 (14.3 acres). 'Icicle' is a new addition to the white lance leaf cultivar group, and, here, we report its origin, tuber yield potential, plant performance in containers and landscapes, and resistance to Fusarium tuber rot, a major fungal disease of caladium that has caused substantial economic losses to the Florida caladium industry (Goktepe et al., 2007).

\section{Origin}

'Icicle' (Fig. 1) originated from a cross between 'Candidum' and 'Gingerland' that was made in Bradenton, FL, in Fall 2004. Both parents are nonpatented commercial cultivars. Reportedly, 'Candidum' was developed by Alfred Bleu, a French pioneer of caladium hybridization, around 1880 (Hayward, 1950). The ancestry of 'Candidum' and 'Gingerland' is unknown. First asexual propagation of 'Icicle' occurred in Balm, FL, in Spring 2006, and since then, it has been asexually propagated through tuber division for 10 generations. Plant, foliar, and growth characteristics of 'Icicle' have been stable and consistent during asexual propagation.

\section{Description}

Description of color (e.g., RHS 200B) for plant parts was based on comparison with the Royal Horticultural Society Color Chart (Royal Horticultural Society, 1986). Plants used for color description were grown from de-eyed, jumbo-sized (or equivalent) tubers (two per container) in $20.3-\mathrm{cm}$ containers in a shaded greenhouse with $\approx 30 \%$ light exclusion. The containers were filled with the potting mix Fafard 3B (Conrad Fafard Inc., Agawam, MA) amended with the commercial controlled release fertilizer Osmocote ${ }^{\circledR}$ (15N-3.9P-10K, 5-6 months; Scotts Co., Marysville, $\mathrm{OH}$ ) at the rate of $4.3 \mathrm{~kg} \cdot \mathrm{m}^{-3}$.

Plants of 'Icicle' are $\approx 29 \mathrm{~cm}$ tall and $60 \mathrm{~cm}$ wide and produce upright, outwardly arching leaves. Mature leaves have an average size of $25 \mathrm{~cm}$ (length) $\times 17.5 \mathrm{~cm}$ (width). Leaves are sagittate-cordate, $23-27 \mathrm{~cm}$ long and $16.5-18.5 \mathrm{~cm}$ wide, and slightly undulate with white (RHS 155D) penniform venation. The upper surface has green (RHS 137A) margins, up to $10 \mathrm{~mm}$ wide, bordering the entire leaf except for the basal leaf valley formed by the two lobes where there may be a 1-2-mm-wide red-purple (RHS 60A) band or spot. The central vein is white (RHS 155D) and primary veins are yellow-green (RHS 145C). Interveinal leaf areas are white (RHS 155D) except for the areas near the margins where irregular grayed green (RHS 191C) mottling and blotching of green (RHS 137A) are present. The abaxial surface has grayed green (RHS 191A) margins, up to $10 \mathrm{~mm}$ wide, and a white (RHS 155D) center with blotching of green (RHS 137A) toward the margins. The central vein is white (RHS $155 \mathrm{~A}$ ) and primary veins are white (RHS $155 \mathrm{~A})$ with a thin line of yellow-green (144B) running down in the center. Petioles are $\approx 5 \mathrm{~mm}$ and yellow-green (RHS 144D) at the apex, but the color diffuses into grayed green (RHS 195A) with blotching of black (RHS 202A) near the base, which is $\approx 9 \mathrm{~mm}$ in diameter. Jumbo-sized tubers are multisegmented, bearing five to nine dominant buds. Tuber surfaces are brown (RHS 200C), with the cortical area being yellow (RHS 10C).

\section{Tuber Yield Potential}

'Icicle' was evaluated for tuber production and plant performance at the GCREC in Balm, FL, in 2010 and 2014. The soil was EauGallie fine sand with about $1 \%$ organic matter and a $\mathrm{pH}$ between 6.2 and 7.4. Caladium plants were grown in the field using a plastic-mulched raised-bed system. In the 2010 season, ground beds $(81 \mathrm{~cm}$ wide and 20 $\mathrm{cm}$ high) were fumigated on 21 Mar. with a mixture of $80 \%$ methyl bromide and $20 \%$ chloropicrin (by volume) at $196 \mathrm{~kg} \cdot \mathrm{ha}^{-1}$. Caladium seed tubers were treated in hot

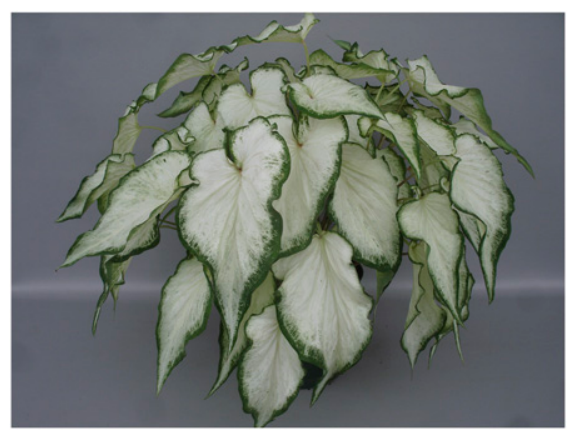

Fig. 1. A typical plant of 'Icicle' (approximately 50-day-old) forced from three No. 1-sized (3.8-6.4 $\mathrm{cm}$ diameter), de-eyed tubers in a $20.3-\mathrm{cm}$ container. Tubers were planted in late Feb. 2014; the plant was grown in a greenhouse with approximately $30 \%$ light exclusion and the photo was taken by G. Bowman on $21 \mathrm{Apr}$. 2014. 
Table 1. Weight, marketable number, production index, and grade distribution of tubers produced by 'Icicle' and two commercial caladium cultivars (checks) in experimental field plots (2010 and 2014). Values presented are means of three plots with 21 propagules planted in a plot of 0.8 m ${ }^{2}$ in 2010 or with 30 propagules planted in a plot of $1.2 \mathrm{~m}^{2}$ in 2014 .

\begin{tabular}{|c|c|c|c|c|c|c|c|}
\hline \multirow[b]{2}{*}{ Cultivar } & \multicolumn{3}{|c|}{ Tuber } & \multicolumn{4}{|c|}{ Tuber grade distribution (\%) } \\
\hline & Weight $(\mathrm{kg})$ & Marketable (no.) & Production index ${ }^{z}$ & Mammoth & Jumbo & No. 1 & No. 2 \\
\hline \multicolumn{8}{|c|}{2010} \\
\hline Icicle & $2.29 \mathrm{a}$ & $28.0^{\mathrm{NS}}$ & $81.3 \mathrm{a}$ & $9.7 \mathrm{a}$ & $34.8^{\mathrm{NS}}$ & $39.1^{\mathrm{NS}}$ & $16.3^{\mathrm{NS}}$ \\
\hline Florida White Ruffles & $1.15 \mathrm{~b}$ & 19.0 & $41.7 \mathrm{~b}$ & $0.0 \mathrm{~b}$ & 20.6 & 49.4 & 30.0 \\
\hline$P$ value & 0.002 & 0.184 & 0.023 & 0.040 & 0.057 & 0.356 & 0.128 \\
\hline \multicolumn{8}{|c|}{2014} \\
\hline Icicle & $1.82^{\mathrm{NS}}$ & $36.3^{\mathrm{NS}}$ & $71.3^{\mathrm{NS}}$ & & $14.1^{\mathrm{NS}}$ & $52.7^{\mathrm{NS}}$ & $33.1^{\mathrm{NS}}$ \\
\hline White Wing & 1.99 & 29.7 & 62.3 & & 16.9 & 56.8 & 26.3 \\
\hline$P$ value & 0.496 & 0.225 & 0.634 & & 0.910 & 0.540 & 0.427 \\
\hline
\end{tabular}

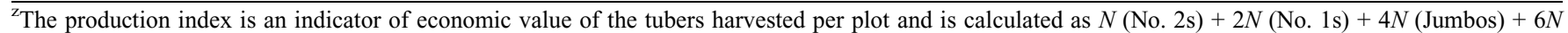

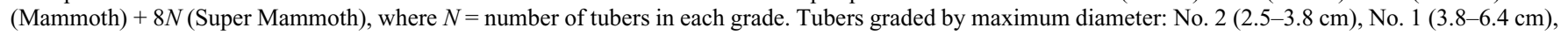

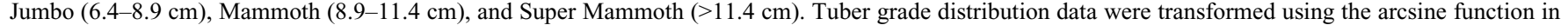
Excel $\{$ asin [sqrt (tuber grade distribution in percentage/100)] .

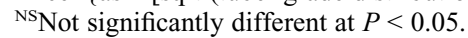

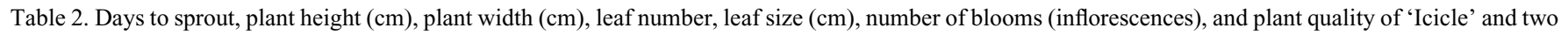
commercial caladium cultivars (checks) grown from No. 1 tubers in 11.4-cm containers in a shaded glasshouse in Balm, FL (2012). Values represent the means of seven plants produced from intact or de-eyed No. $1(3.8-6.4 \mathrm{~cm}$ in diameter) tubers planted individually per container.

\begin{tabular}{|c|c|c|c|c|c|c|c|c|c|c|c|c|c|c|c|c|}
\hline \multirow[b]{2}{*}{ Cultivar } & \multicolumn{2}{|c|}{ Days to sprout ${ }^{z}$} & \multicolumn{2}{|c|}{ Plant ht $(\mathrm{cm})$} & \multicolumn{2}{|c|}{ Plant width $(\mathrm{cm})$} & \multicolumn{2}{|c|}{ Leaves (no.) } & \multicolumn{2}{|c|}{ Leaf length $(\mathrm{cm})$} & \multicolumn{2}{|c|}{ Leaf width $(\mathrm{cm})$} & \multicolumn{2}{|c|}{ Blooms (no.) } & \multicolumn{2}{|c|}{ Quality rating $^{\mathrm{y}}$} \\
\hline & Intact & $\overline{\text { De-eye }}$ & Intact & $\overline{\text { De-eye }}$ & Intact & $\overline{\text { De-eye }}$ & Intact & $\overline{\text { De-eye }}$ & Intact & $\overline{\text { De-eye }}$ & Intact & $\overline{\text { De-eye }}$ & Intact & De-eye & Intact & De-eye \\
\hline Icicle & $19.0 \mathrm{~b}$ & $20.4 \mathrm{~b}$ & $26.1 \mathrm{a}$ & $24.0 \mathrm{~b}$ & $39.6^{\mathrm{NS}}$ & $36.9^{\mathrm{NS}}$ & $23.4 \mathrm{a}$ & $57.1 \mathrm{a}$ & $22.5 \mathrm{a}$ & $15.4 \mathrm{a}$ & $15.2 \mathrm{a}$ & $9.7 \mathrm{a}$ & $0.7 \mathrm{~b}$ & $0.0^{\mathrm{NS}}$ & $4.0 \mathrm{a}$ & $4.6^{\mathrm{NS}}$ \\
\hline $\begin{array}{l}\text { Florida White } \\
\text { Ruffles }\end{array}$ & $27.9 \mathrm{a}$ & $26.0 \mathrm{a}$ & $22.3 \mathrm{~b}$ & $17.6 \mathrm{c}$ & 42.7 & 35.8 & $31.6 \mathrm{a}$ & $63.4 \mathrm{a}$ & $16.5 \mathrm{~b}$ & $12.6 \mathrm{~b}$ & $9.4 \mathrm{c}$ & $6.8 \mathrm{~b}$ & $0.4 \mathrm{~b}$ & 0.0 & $3.2 \mathrm{~b}$ & 4.2 \\
\hline White Wing & $25.4 \mathrm{a}$ & $27.1 \mathrm{a}$ & $28.7 \mathrm{a}$ & $28.7 \mathrm{a}$ & 39.4 & 37.6 & $13.3 \mathrm{~b}$ & & & $16.4 \mathrm{a}$ & & & & 0.3 & & 4.1 \\
\hline$P$ value & $<0.001$ & 0.001 & 0.007 & $<0.001$ & 0.264 & 0.616 & 0.002 & $<0.001$ & $<0.001$ & 0.007 & $<0.001$ & $<0.001$ & 0.020 & 0.133 & 0.007 & 0.115 \\
\hline
\end{tabular}

${ }^{\mathrm{z}}$ Number of days from planting to the first unfurled leaf. Mean separation within column for each cultivar by the least significant difference test at $P<0.05$.

${ }^{y}$ Quality of the potted caladium plants was rated on a scale of 1 to 5 , with $1=$ very poor, unattractive, and totally unacceptable as potted plants with few leaves and 5 = very attractive, full plants with a symmetrical shape, an appropriate height, and many bright, colorful leaves.

${ }^{\mathrm{NS}}$ Mean values within column are not significantly different at $P<0.05$.

water $\left(50{ }^{\circ} \mathrm{C}\right)$ for $30 \mathrm{~min}$. Caladium seed pieces (tuber pieces, $\approx 2.5 \times 2.5 \times 2.5 \mathrm{~cm}$ ) were planted manually on 9 Apr. with $\approx 25.4$ $\mathrm{cm}$ between-row spacing and $\approx 15.2 \mathrm{~cm}$ inrow spacing. Irrigation was through a seepage system (Geraldson et al., 1965), which maintained a relatively consistent water table below the covered beds. Two teaspoons $(\approx 14 \mathrm{~g})$ of Osmocote ${ }^{\circledR}(15 \mathrm{~N}-2.6 \mathrm{P}-10 \mathrm{~K}, 8-$ 9 months) was applied to each plant on 18 May. One additional teaspoon $(\approx 7 \mathrm{~g})$ of Osmocote $^{\circledR}$ was applied on 13 Aug. New crop tubers were dug, washed, and dried on 3-6 Dec. 2010. Dried tubers from each experimental field plot were weighed, graded, and counted in mid-Jan. 2011, as described by Deng and Harbaugh (2006). Tuber grading was by the maximum diameter: Super Mammoth (greater than $11.4 \mathrm{~cm}$ ), Mammoth (8.9-11.4 cm), Jumbo (6.4-8.9 $\mathrm{cm})$, No. $1(3.8-6.4 \mathrm{~cm})$, and No. 2 (2.5-3.8 $\mathrm{cm})$. Tuber grades and counts were converted into a production index to show the relative economic value of the harvested tubers per field plot: Production index $=8 n$ (Supper Mammoth $)+6 n$ (Mammoth $)+4 n$ (Jumbo $)+$ $2 n$ (No. 1) $+1 n$ (No. 2), where $n=$ number of tubers in the grade. The relative values assigned to the five tuber grades in calculating production index were based on the relative market prices provided by Florida caladium tuber producers.

For the 2014 evaluation, beds were fumigated on 9 Jan. with Pic-Clor $60^{\circledR}(39.0 \%$ 1,3dichloropropene and $59.6 \%$ chloropicrin) at $448 \mathrm{~kg} \cdot \mathrm{ha}^{-1}$. Plantacote ${ }^{\circledR}$ Pluss, a controlled release fertilizer $(14 \mathrm{~N}-3.9 \mathrm{P}-12.5 \mathrm{~K}, 12$ months, X-Calibur Plant Health Company, LLC, Summerville, SC), was incorporated into the bed at $336 \mathrm{~kg} \cdot \mathrm{ha}^{-1}$. Caladium seed pieces were planted on $26 \mathrm{Apr}$. at $\approx 15$-cm spacing between rows and in rows. Irrigation was by seepage, as described by Geraldson et al. (1965). Caladium plants were fertilized with $600 \mathrm{ppm}$ of nitrogen with a commercial water-soluble fertilizer (20N-8.7P-16.6K, Southern Agricultural Insecticides, Inc., Palmetto, FL) on 18 Sept. and 1 Oct. 2014. Tubers were dug from 1 Dec. to 9 Dec. 2014, followed by the same washing, drying, weighing, grading, and counting procedures as were carried out in 2010.

In both seasons, field plots were arranged in a randomized complete block design with three replications. The plot size in the 2010 season was $0.8 \mathrm{~m}^{2}$ and was planted with 21 caladium propagules, whereas the plot size in the 2014 season was $1.2 \mathrm{~m}^{2}$ and was planted with 30 caladium propagules (tuber pieces). The commercial cultivar Florida White Ruffles or White Wing was included in the field as checks to assess the tuber yield and plant performance of 'Icicle'. Analysis of variance was conducted using the JMP Pro 12 program, followed by pairwise mean comparisons using the least significant difference (SAS Institute, 2016).

The tuber weight and production index of 'Icicle' in 2010 were $2.29 \mathrm{~kg}$ and 81.3 , respectively, which were $95.0 \%$ to $99.0 \%$ greater than 'Florida White Ruffles' tuber weight and production index (Table 1). In the

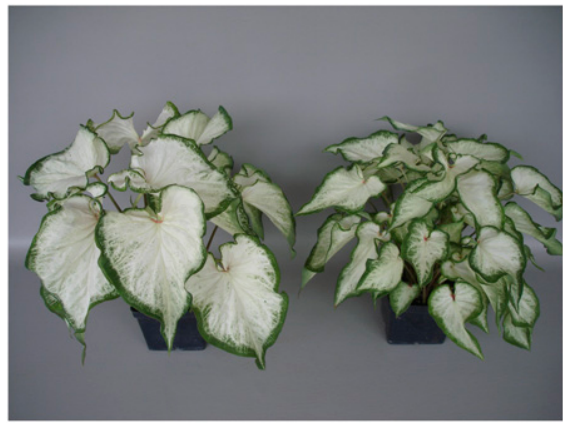

Fig. 2. Plants of 'Icicle' forced in small containers One intact (left) and one de-eyed (right) No. 1 tuber (3.6-6.4 cm in diameter) were planted in 12.7-cm square containers on 13 Apr. 2012; plants were grown in a shaded greenhouse and the photo was taken by G. Bowman on 8 June 2012 .

2014 season, 'Icicle' and 'White Wing' did not show significant differences in tuber weight, marketable number, and production index (Table 1). Also, there were no significant differences in tuber grade distribution between 'Icicle' and 'Florida White Ruffles' or 'White Wing' (Table 1). The primary grade of their tubers was the No. 1 .

\section{Container Trials}

The suitability of 'Icicle' for container plant production was evaluated by forcing tubers in $11.4-\mathrm{cm}$ containers (diameter) in 
Spring 2012, following the protocol of Harbaugh and Tjia (1985). Number 1-sized tubers were planted on $13 \mathrm{Apr}$. in a commercial potting mix (Fafard 3B) amended with Osmocote ${ }^{\circledR}$ fertilizer $(15 \mathrm{~N}-3.9 \mathrm{P}-10 \mathrm{~K}, 5-6$ months) at $4.3 \mathrm{~kg} \cdot \mathrm{m}^{-3}$; plants were grown in a greenhouse with $\approx 30 \%$ light exclusion. Temperatures in the greenhouse ranged from

$16{ }^{\circ} \mathrm{C}$ (night) to $30{ }^{\circ} \mathrm{C}$ (day). Potted plants were arranged on metal benches in the greenhouse in a randomized complete block design with seven replications. Plant height, plant width, number of leaves, and foliar characteristics were recorded on 11 June 2012, about 8 weeks after planting. Quality of the potted caladium plants was rated on

Table 3. Characteristics of 'Icicle' and two commercial caladium cultivars grown from tuber propagules $(\approx 2.5 \mathrm{~cm})$ in ground beds in full sun in Balm, FL (2010 and 2014).

\begin{tabular}{lcccc}
\hline Cultivar & Plant ht $(\mathrm{cm})^{\mathrm{z}}$ & Leaf number $^{\mathrm{z}}$ & ${\text { Leaf length }(\mathrm{cm})^{\mathrm{z}}}^{\mathrm{y}}$ & ${\text { Leaf width }(\mathrm{cm})^{\mathrm{z}}}^{\mathrm{n}}$ \\
\hline & $37.2 \mathrm{a}$ & 2010 & & \\
Icicle & $15.5 \mathrm{~b}$ & $32.1^{\mathrm{NS}}$ & $22.1 \mathrm{a}^{\mathrm{y}}$ & $12.6 \mathrm{a}$ \\
Florida White Ruffles & 0.009 & 0.966 & $13.9 \mathrm{~b}$ & $6.0 \mathrm{~b}$ \\
$P$ value & & 2014 & 0.032 & 0.014 \\
& $23.5^{\mathrm{NS}}$ & $20.3 \mathrm{a}$ & $18.9^{\mathrm{NS}}$ & $11.2^{\mathrm{NS}}$ \\
Icicle & 28.5 & $9.8 \mathrm{~b}$ & 20.0 & 11.5 \\
White Wing & 0.321 & 0.011 & 0.562 & 0.826 \\
$P$ value &
\end{tabular}

${ }^{\mathrm{z}}$ Values presented for plant height $(\mathrm{cm})$ and leaf number, length $(\mathrm{cm})$, and width $(\mathrm{cm})$ were means of three plots with three or four plants measured per plot per year.

${ }^{y}$ Mean separation within columns by the least significant difference test at $P<0.05$.

${ }^{\mathrm{NS}}$ Not significantly different.

Table 4. Plant performance ratings of 'Icicle' and two commercial caladium cultivars grown from 2.5 -cm tuber propagules in ground beds in full sun in Balm, FL (2010 and 2014). Performance ratings are means of three plots based on whole plot evaluation in each evaluation.

\begin{tabular}{lcccccccc}
\hline \multicolumn{7}{c}{ Plant performance rating } \\
\hline Cultivar & July & Aug. & Sept. & Oct. & July & Aug. & Sept. & Oct. \\
\hline & 2010 & 2010 & 2010 & 2010 & 2014 & 2014 & 2014 & 2014 \\
Icicle & $2.9^{\mathrm{NS}}$ & $3.9 \mathrm{a}^{\mathrm{y}}$ & $4.3 \mathrm{a}$ & $4.5 \mathrm{a}$ & $3.0^{\mathrm{NS}}$ & $3.5^{\mathrm{NS}}$ & $3.8^{\mathrm{NS}}$ & $3.7^{\mathrm{NS}}$ \\
Florida White Ruffles & 2.3 & $2.8 \mathrm{~b}$ & $2.7 \mathrm{~b}$ & $3.0 \mathrm{~b}$ & $-\overline{\mathrm{x}}^{\mathrm{x}}$ & $-\bar{c}$ & $-\bar{c}$ & $-\overline{-}$ \\
White Wing & - & - & - & - & 3.2 & 3.3 & 3.3 & 3.2 \\
$P$ value & 0.094 & 0.006 & 0.003 & 0.000 & 0.667 & 0.184 & 0.369 & 0.074 \\
\hline
\end{tabular}

${ }^{\mathrm{z}}$ Plants were rated on a scale of 1 to 5 , with 1 being very poor, 3 being fair and acceptable, and 5 being excellent in plant vigor, fullness, and color display.

${ }^{\mathrm{y}}$ Mean separation within columns by the least significant difference test at $P<0.05$.

${ }^{\mathrm{x}}$ Plants were not evaluated and data were unavailable.

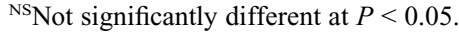

Table 5. Sunburn tolerance of 'Icicle' and two commercial caladium cultivars grown from 2.5 -cm tuber propagules in ground beds in full sun in Balm, FL (2010 and 2014). Sunburn tolerance ratings are means of three plots based on whole plot evaluation in each evaluation.

\begin{tabular}{lcccccccc}
\hline \multicolumn{8}{c}{ Sunburn tolerance rating } \\
\hline Cultivar & July & Aug. & Sept. & Oct. & July & Aug. & Sept. & Oct. \\
\hline & 2010 & 2010 & 2010 & 2010 & 2014 & 2014 & 2014 & 2014 \\
Icicle & $3.3^{\mathrm{NS}}$ & $3.7^{\mathrm{NS}}$ & $3.9 \mathrm{a}^{\mathrm{y}}$ & $3.6^{\mathrm{NS}}$ & $3.6^{\mathrm{NS}}$ & $3.3^{\mathrm{NS}}$ & $3.7^{\mathrm{NS}}$ & $2.6^{\mathrm{NS}}$ \\
Florida White Ruffles & 3.3 & 3.8 & $3.3 \mathrm{~b}$ & 3.3 & $-\overline{-}^{\mathrm{x}}$ & $-\overline{-}$ & $-\overline{1}$ & $-\overline{3}$ \\
White Wing & - & - & - & - & 4.3 & 3.8 & 3.4 & 3.3 \\
$P$ value & 0.742 & 0.423 & 0.020 & 0.478 & 0.094 & 0.230 & 0.478 & 0.184 \\
\hline
\end{tabular}

${ }^{\mathrm{z}}$ Caladium plant sunburn tolerance was rated on a scale of 1 to 5 , with 1 being very poor, 3 being fair and acceptable, and 5 being excellent without showing any signs of leaf burns or resulted holes on leaf surfaces.

${ }^{\mathrm{y}}$ Mean separation within columns by the least significant difference test at $P<0.05$.

${ }^{\mathrm{x}}$ Plants were not evaluated and data were unavailable.

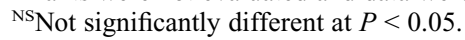

a scale of 1 to 5 , with 1 = very poor, unattractive, and totally unacceptable as potted plants with few leaves and $5=$ very attractive, full plants with a symmetrical shape, an appropriate height, and many bright, colorful leaves.

Intact tubers of 'Icicle' sprouted $19 \mathrm{~d}$ after planting, approximately 6-9 d earlier than those of 'Florida White Ruffles' or 'White Wing' (Table 2). Plants of 'Icicle' from the intact tubers (Fig. 2) had an average height and width of 26.1 and $39.6 \mathrm{~cm}, 3.8 \mathrm{~cm}$ taller than plants of 'Florida White Ruffles' but similar to plants of 'White Wing' in height and width (Table 2). Plants of 'Icicle' produced much longer (by $36.4 \%$ ) and wider (by $61.7 \%$ ) leaves than plants of 'Florida White Ruffles'. The former also received a higher quality rating ( 4.0 vs. 3.2). Plants of 'Icicle' produced $75.9 \%$ more leaves than 'White Wing', and leaves were $2.3-\mathrm{cm}$ wider than leaves of 'White Wing'. Plants of 'Icicle' were of much higher quality than those of 'White Wing' (4.0 vs. 2.7) (Table 2).

De-eyed tubers of 'Icicle' sprouted in approximately $20 \mathrm{~d}$ after planting and 5-7 d earlier than 'Florida White Ruffles' or 'White Wing' (Table 2). On average, plants of 'Icicle' forced from de-eyed tubers (Fig. 2) were 24.0 $\mathrm{cm}$ high and $36.9 \mathrm{~cm}$ wide, which were intermediate between 'Florida White Ruffles' and 'White Wing'. De-eyed 'Icicle' plants were significantly different from de-eyed 'Florida White Ruffles' in that the former had $22.2 \%$ longer and $42.6 \%$ wider leaves. De-eyed 'Icicle' plants were distinct from 'White Wing' in that the former produced almost 1-fold more leaves than the latter.

\section{Landscape Performance}

The landscape performance of 'Icicle' was evaluated in 2010 and 2014, on the same plots used for evaluating tuber production. A scale of 1 to 5 was used with 1 being very poor (few leaves and lack of vigor) and 5 being excellent (full plants, numerous leaves, and bright color display). Leaf sunburn tolerance was evaluated on a scale of 1 to 5 , with 1 being very susceptible to sunburn (leaves having numerous sun-damaged areas or holes) and 5 being resistant to sunburn (no visible sun-damaged areas). Evaluations of plant performance and sunburn tolerance were carried out in July, Aug., Sept., and Oct. 2010, and July, Aug., Sept., and Oct. in

Table 6. Lesion diameters ( $\mathrm{mm}$ ) on tuber halves of 'Icicle' and five commercial caladium cultivars inoculated with three isolates of Fusarium solani (13-341, 05257, and 05-20) in two experiments in 2013.

\begin{tabular}{|c|c|c|c|c|c|c|c|c|}
\hline \multirow[b]{2}{*}{ Cultivar } & \multicolumn{3}{|c|}{$F$. solani isolates in Expt. 1} & \multicolumn{3}{|c|}{$F$. solani isolates in Expt. 2} & \multirow{2}{*}{$\begin{array}{l}\text { Avg lesion } \\
\operatorname{diam}(\mathrm{mm})\end{array}$} & \multirow[b]{2}{*}{ Resistance category } \\
\hline & $13-341$ & $05-257$ & $05-20$ & $13-341$ & $05-257$ & $05-20$ & & \\
\hline 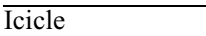 & $5.8^{\mathrm{NS}}$ & $6.4^{\mathrm{NS}}$ & $5.0 \mathrm{~b}^{\mathrm{z}}$ & $4.7^{\mathrm{NS}}$ & $5.5 \mathrm{bc}$ & $4.1 \mathrm{c}$ & 5.2 & Resistant to moderately resistant ${ }^{y}$ \\
\hline Candidum & 4.0 & 6.6 & $5.5 \mathrm{~b}$ & 4.7 & $5.0 \mathrm{bc}$ & $4.4 \mathrm{bc}$ & 5.0 & Resistant $^{\mathrm{x}}$ \\
\hline White Christmas & 4.4 & 7.1 & $4.9 \mathrm{~b}$ & 4.7 & $3.9 \mathrm{c}$ & $4.1 \mathrm{c}$ & 5.0 & Resistant $^{\mathrm{x}}$ \\
\hline Red Flash & 6.0 & 9.5 & $6.3 \mathrm{~b}$ & 6.5 & $6.5 \mathrm{bc}$ & $6.9 \mathrm{~b}$ & 7.0 & Moderately resistant ${ }^{\mathrm{x}}$ \\
\hline Carolyn Whorton & 7.6 & 9.5 & $6.7 \mathrm{~b}$ & 5.3 & $9.7 \mathrm{ab}$ & $6.4 \mathrm{bc}$ & 7.6 & Highly susceptible ${ }^{x}$ \\
\hline Freida Hemple & 7.0 & 9.7 & $13.0 \mathrm{a}$ & 6.5 & $12.9 \mathrm{a}$ & $10.3 \mathrm{a}$ & 9.9 & Highly susceptible ${ }^{\mathrm{x}}$ \\
\hline$P$ value & 0.563 & 0.280 & 0.003 & 0.355 & 0.012 & 0.001 & & \\
\hline
\end{tabular}

${ }^{\mathrm{z}}$ Mean separation within columns by the least significant difference test at $P<0.05$.

${ }^{\mathrm{y}}$ Based on comparison with five commercial caladium cultivars included in the experiments.

${ }^{\mathrm{x}}$ The resistance levels of these commercial cultivars were reported by Goktepe et al. (2007).

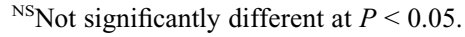


2014. Plant height, number of leaves per plant, and leaf size (maximum length and width) were measured on three plants arbitrarily chosen from each plot, approximately 4 months after planting.

Plants of 'Icicle' grown in the ground beds had an average height of $30.4 \mathrm{~cm}, 4.9$ $\mathrm{cm}$ taller than that of 'Florida White Ruffles' (Table 3). Leaves of 'Icicle' were $20.5 \mathrm{~cm}$ long and 11.9 wide, significantly longer and wider than the leaves of 'Florida White Ruffles' $(13.9 \times 6.0 \mathrm{~cm})$. Plants of 'Icicle' had an average of 26.2 leaves per plant, approximately 1.6 times more than the number of leaves 'White Wing' plants produced (Table 3).

'Icicle' performed relatively well in both 2010 and 2014 growing seasons, with performance ratings between 2.9 and 4.5 in 2010 and between 3.0 and 3.8 in 2014 (Table 4). Its performance ratings were significantly higher than those of 'Florida White Ruffles' (2.3-2.8) in three evaluations in 2010. 'Icicle' showed a moderate level of sunburn tolerance in the 2010 and 2014 growing seasons, with sunburn tolerance ratings between 2.6 and 3.9 (Table 5). Its sunburn tolerance ratings were higher than those of 'Florida White Ruffles' (3.3-3.8) in one evaluation but lower than those of 'White Wing' (3.3-4.3) in one evaluation.

\section{Resistance to Fusarium Tuber Rrot}

'Icicle' was compared with selected caladium cultivars regarding its susceptibility to Fusarium tuber rot. Caladium tubers of 'Icicle' and commercial cultivars Candidum, Carolyn Whorton, Freida Hemple, Red Flash, and White Christmas were surface-sterilized, cut in half, and inoculated with Fusarium solani by inserting two pieces of Fusariumcolonized carnation leaf segments (Goktepe et al., 2007). Inoculated tuber halves were placed inside egg cartons and incubated at $18^{\circ} \mathrm{C}$ under $\approx 100 \%$ relative humidity. Tubers were screened with three highly aggressive $F$. solani isolates (13-341, 05-20, and 05-527), and the diameter of the lesion caused by Fusarium was measured 2 weeks after inoculation. 'Candidum' (resistant), 'Carolyn Whorton' (highly susceptible), 'Freida Hemple' (high susceptible), 'Red Flash' (moderately resistant), and 'White Christmas' (resistant) were evaluated previously and were placed into three categories (resistant, moderately resistant, or highly susceptible) (Goktepe et al., 2007). Based on two experiments conducted in 2013 for Fusarium tuber rot, 'Icicle' was considered resistant to moderately resistant to Fusarium tuber rot (Table 6).

\section{Recommendation}

'Icicle' is characterized by wide lance leaves with a large white center surrounded by green margins. It is expected to produce high-quality pot plants without de-eyeing and perform well in shady landscapes. Tubers of 'Icicle' can sprout 5-9 d earlier than 'Florida White Ruffles' and 'White Wing', which may result in a shorter production cycle to greenhouse growers. 'Icicle' has showed higher tuber yield potential than 'Florida White Ruffles'.

\section{Availability}

'Icicle' was released under the name 'UFR1022'. Plant patent has been applied for 'Icicle' by the Florida Agricultural Experiment Station. Commercial production of this cultivar is required to have licensing agreements with the Florida Foundation Seed Producers, Inc., P.O. Box 309, Greenwood, FL 32443. Information on tuber availability and licensing agreements can be obtained from the Florida Foundation Seed Producers, Inc. (http://www.ffsp.net/).

\section{Literature Cited}

Baldwin, B.D., G.J. Wilfret, and B.K. Harbaugh. 2002. 'Florida White Ruffles' - A white strapleaved caladium for small pots, hanging baskets, or sunny landscapes. HortScience 37: 838-840.

Bell, M.L., G.J. Wilfret, and D.A. DeVoll. 1998. Survey of caladium tuber producers for acreage of cultivars grown. Proc. Annu. Meet. Fla. State Hort. Soc. 111:32-34.

Deng, Z. and B.K. Harbaugh. 2006. 'Garden White'-A large white fancy-leaved caladium for sunny landscapes and large containers. HortScience 41:840-842.

Deng, Z., B.K. Harbaugh, R.K. Schoellhorn, and R.C. Andrew. 2008. 2003 Survey of the Florida caladium tuber production industry. Univ. Florida/IFAS extension fact sheet, ENH 1007. 16 July 2010. <http://edis.ifas.ufl.edu/ EP258>.

Evans, M.R., G.J. Wilfret, and B.K. Harbaugh. 1992. Caladiums as potted and landscape plants. IFAS, Univ. Florida. Agr. Ext. Serv. Circ. $1060.6 \mathrm{pp}$.

Geraldson, C.M., A.J. Overman, and J.P. Jones. 1965. Combination of high analysis fertilizers, plastic mulch and fumigation for tomato production on old agricultural land. Proc. Soil Crop Sci. Soc. Fla. 25:18-24.

Goktepe, F., T. Seijo, Z. Deng, B.K. Harbaugh, and N.A. Peres. 2007. Toward breeding for resistance to Fusarium tuber rot in caladium: Inoculation technique and sources of resistance. HortScience 42:1135-1139.

Harbaugh, B.K. and B.O. Tjia. 1985. Commercial forcing of caladiums. IFAS. Univ. Florida Agr. Ext. Serv. Circ. 621. 13 pp.

Hayward, W. 1950. Fancy-leaved caladiums. Plant Life 6:131-142.

Royal Horticultural Society. 1986. RHS Colour Chart. Royal Hort. Soc., London.

SAS Institute. 2016. JMP ${ }^{\circledR}$ Pro 12.0.1. SAS Inst., Cary, NC. 